\title{
KONSEP SADD AI-DZARI'AH DALAM PERSPEKTIF IBNU AL-QAYYIM AL-JAUZIYAH
}

\author{
Oleh: \\ Imam Fawaid \\ Universitas Ibrahimy Situbondo, Indonesia \\ fawaidmyel@gmail.com
}

\begin{abstract}
:
This Islamic law will continue to go along with the dynamics and changing of the era. The more complex real problems in society require fiqh experts to always be sensitive to reality. In producing the law, the jurists use various tools to produce laws that are in harmony with the benefit of mankind. This research is seen from the problems to be examined, the data collected is qualitative because it is in the form of thought, namely the conception of sadd al-dzarî'ah which was built by Islamic legal experts (fuqahâ 'and ushûliyyîn) in general and views on sadd al-dzarî'ah which was designed by Ibn al-Qayyim al-Jauziyah in his book I'lâm al-Muwaqqi'în. The concept of al-Dzarî'ah according to Ibn al-Qayyim can be used as an argument to establish the law. While the legal provisions of al-Dzarî'ah follow its (purpose). If the Ghâyah is in the form of benefit, then al-Dzarî'ah is opened and permitted, whereas if the Ghâyah is in the form of mafsadat, then al-Dzarî'ah is closed and prevented. The latter is what is called Sadd al-Dzarî'ah. For Ibn alQayyim Sadd al-Dzarî'ah, it can be used as an argument in determining the law because many texts of the Koran and Sunnah practice the concept of Sadd al-Dzarî'ah. Implicitly, these texts have legalized Sadd al-Dzarî'ah. However, if the practice in the field of Sadd al-Dzarî'ah is contrary to maslahat or hâjat, then Sadd al-Dzarî'ah is defeated. Benefits and hâjat are prioritized more than Sadd al-Dzarî'ah.
\end{abstract}

Keyword: Ibnu al-Qayyim al-Jauziyah, Sadd al-Dzarî'ah, Argumen Ahkam.

\section{A. Pendahuluan}

Sebagaimana maklum, bahwa perkembangan zaman yang seiring dengan perkembangan sains dan teknologi memunculkan beragam kasus yang belum pernah dikenal sebelumnya. Padahal semua kasus itu sangat mendesak untuk mendapat jawaban fiqh. Oleh karena itu, untuk menjawab hukum dari peristiwa-peristiwa baru tidak dapat diselesaikan dengan dalil yang berupa teks. Akan tetapi, hal ini membutuhkan dalildalil di luar teks. 
Diantara dalil yang selain teks yang digunakan oleh para ulama untuk menghasilkan hukum ialah ijmâ', qiyâs, istihsân, istishâb, 'urf, maslahah mursalah, sadd al-dzarî'ah, dan lain-lain. Tidak ada kata sepakat dari para ulama tentang kehujjahan dalil-dalil tersebut. Ada sebagian ulama yang menggunakan dalil tertentu, tetapi ulama lain tidak mengakuinya. Begitu pula sebaliknya. Di dalam menggunakan dan menolak suatu dalil, mereka bertumpu pada landasan dan argumentasi masing-masing. Mereka tentu mempunyai hipotesis bahwa dalil yang dijadikan hujjah tersebut dapat mengantar kepada hukum yang bersifat abstrak. Akibatnya, tarik menarik antara kehujjahan suatu dalil dan tidaknya merupakan suatu keniscayaan.

Timbulnya perbedaan ini merupakan suatu hal yang wajar, mengingat setiap orang mempunyai tipologi pemikiran yang tidak sama dengan orang lain. Sebagian dari mereka mempunyai pemikiran yang lebih memprioritaskan otoritas akal dari pada teks. Tipologi ini bisa jadi terbentuk dari sistem sosial dan masyarakat yang melingkupinya. Seseorang yang hidup di tengah kota metropolis dan jauh dari sumber wahyu yang diturunkan tentunya cenderung untuk lebih banyak menggunakan rasionya.

Di sisi lain, ulama ada yang cenderung tekstual dan hanya menyisakan ruang yang sempit untuk wilayah rasio. Kelompok ini sering dilabeli sebagai kaum tekstualis-literalis. Bahkan sebagian kalangan hanya an sich memandang makna teks secara hitam putih tanpa terkontaminasi peran akal. Seperti madzhab Dhâhiriyah yang semata-mata memandang pada makna luar (dhâhir) teks tanpa memberikan ruang terhadap rasio untuk berkreasi. Bagi kelompok ini, teks al-Qur'an dan hadits merupakan harga mati yang tidak dapat diutak-atik dengan intervensi akal.

Munculnya perbedaan ini disebabkan karena syari' tidak menjelaskan secara pasti mengenai dalil-dalil yang dapat dijadikan pegangan. Syari' hanya memberi rambu-rambu atau isyarat tentang dalil melalui al-Qur'an dan sunnah. Pemahaman para ulama tentang isyaratisyarat ini berbeda-beda. Daya tangkap dan paradigma yang berlainan dapat mengakibatkan perbedaan pandangan di antara mereka.

Dari sekian dalil yang digunakan para ulama, hanya terdapat empat dalil yang disepakati, yakni al-Qur'an, sunnah, ijmấ, dan qiyâs. ${ }^{1}$ Sedangkan dalil-dalil selain empat tersebut masih menjadi perdebatan di antara para ulama. Imam Abû Hanîfah lebih tersohor dengan dalil istihsân-nya, Imam Mâlik dengan 'urf ahli Madinahnya, Imam Syâfi'i dengan qiyâs-nya. Ciri

${ }^{1}$ Wahbah al-Zuhaily, Op cit, Juz I, 417.

324 JURNAL LISAN AL-HAL 
khas para ulama ini didukung oleh situasi dan kondisi yang mengitarinya.

Salah satu dalil yang masih menjadi kontroversi di kalangan para ulama adalah sadd al-dzarî́ah. Tidak ada kata sepakat di kalangan ulama di dalam menggunakan sadd al-dzarî'ah sebagai hujjah. Hal ini dikarenakan tidak ada sandaran yang pasti dari al-Qur'an dan hadits mengenai kehujjahannya. Sadd al-dzarî́ah adalah menutup media yang dapat mengantarkan kepada mafsadat (kerusakan). Sadd al-dzarî̀ah ini ditetapkan sebagai dalil dalam rangka mengambil tindakan preventif akan terjadinya mafsadat.

Diantara kasus-kasus yang ditetapkan dengansadd al-dzarî́ah, yaitu berduaan di tempat sepi dengan seorang perempuan diharamkan karena dapat mengundang kepada mafsadat, yakni berbuat zina. Minum sedikit khamr diharamkan meskipun tidak menyebabkan mabuk karena dapat memotivasi untuk minum lebih banyak sehingga mabuk. Dilarang mencaci maki berhala di hadapan orang musyrik karena dikhawatirkan orangorang musyrik tersebut akan memaki-maki Allah, dan lain-lain.Di era modern ini, banyak sekali terjadi rekayasa hukum dan usaha untuk melegalkan sesuatu yang dilarang. Jika hal ini tidak diantisipasi, niscaya akan lepas dari jangkauan hukum. Teks-teks sumber hukum sangat terbatas, sementara problem kehidupan kian meningkat. Bagi para Juris Islam harus mempunyai senjata yang ampuh untuk dapat menjawab segala persoalan umat khususnya pada era modern ini.

Dengan menggunakan beragam dalil diharapkan dapat menjadi alternatif di dalam menetapkan hukum, khususnya problem-problem kontemporer. Setidaknya, sadd al-dzarî'ah dapat dijadikan sarana untuk mengantisipasi terjadinya bentuk rekayasa-rekayasa hukum. Seiring dengan perkembangan ilmu pengetahuan, konsep sadd al-dzarî́ah pun mengalami perkembangan. Baik ulama yang mengakui kehujjahan sadd aldzarî'ah maupun yang menolaknya.

Diantara ulama' yang mengakui kehujjahan sadd al-dzari'ah adaah Ibnu al-Qayyim al-Jauziyah. Beliau merupakan salah satu pakar fiqh-ushul fiqh madzhab Hanbali yang mewarnai peta pemikiran ushul fiqh di kalangan para ushuly dan fuqaha. Ulama kelahiran Damascus ini telah menghasilkan puluhan kitab-kitab yang masih beredar sampai sekarang dan dijadikan referensi di setiap perbincangan ushul fiqh.

Salah satu karya master piece-nya, I'lâm al-Muwaqqi'în banyak mengungkap beragam kasus-kasus fiqhiyyah dan dikemas dengan apik dengan mengungkapkan argumen-argumen fiqhiyyah. Di dalamnya banyak diungkapkan pemikiran-pemikiran yang menjadi ciri khas Ibnu al-Qayyim.

Ibnu al-Qayyim termasuk tokoh yang terkenal dengan ulama yang 
rasional. Dengan rasionya, ia sering memunculkan ide-ide segar yang dapat menumbuhkan dinamika pemikiran hukum Islam. Tentunya, ulama sekaliber Ibnu al-Qayyim mempunyai pemikiran segar tentang konsep sadd al-dzarî̀ah. Sebagai tokoh yang sering mendengungkan aktifitas ijtihad dan bahkan secara tegas menolak tertutupnya pintu ijtihad, Ibnu alQayyim memberikan porsi khusus bagi sadd al-dzarî'ah sebagai salah satu metode berijtihad.

Sadd al-dzarî́ah sebagai salah satu dalil yang diproyeksikan untuk menutup kebuntuan hukum tatkala nash tidak memberikan jawaban hukum. Dalam hal ini sadd al-dzarî'ah membutuhkan peran akal dalam proses berijtihad. Di samping konsep sadd al-dzarî'ah yang dibangun Ibnu al-Qayyim penting juga diungkap argumentasi-argumentasi dan latar belakang munculnya konsep tersebut. Dengan itu semua, memungkinkan untuk menelaah dan menganalisa lebih mendalam untuk mengaplikasikan sadd al-dzarî'ah dalam menjawab persoalan kontemporer.

Dalam penelitian ini menggunakan pendekatan kualitatif karena data yang dikumpulkan berupa pemikiran, yaitu konsepsadd al-dzarî̀ah yang dibangun oleh para pakar hukum Islam (fuqahâ' dan ushûliyyîn) secara umum dan pandangan tentang sadd al-dzarî'ah yang dirancang oleh Ibnu al-Qayyim al-Jauziyah dalam kitabnya I'lâm al-Muwaqqi'în.Jenis penelitian yang digunakan adalah library research (penelitian kepustakaan). Dalam arti, mengkaji dan meneliti sumber-sumber kepustakaan serta menggunakan bahan-bahan tertulis dalam bentuk kitab, buku dan sumber-sumber tertulis lainnya yang berkaitan dengan tema bahasan ${ }^{2}$, yaitu karya-karya dalam bidang fiqh dan ushul fiqh.

Oleh karena itu, cukup urgen untuk menganalisis bagaimana pemikiran Ibnu al-Qayyim al-Jauziyah tentang sadd al-dzarî'ah, sedangkan beliau merupakan representasi ulama yang bertipologi rasional.

\section{B. Biografi Ibnu al-Qayyim al-Jauziyah}

Ibnu al-Qayyim al-Jauziyah merupakan salah satu tokoh madzhab Hanbali yang pemikirannya selalu menghiasi lembaran kitab-kitab turâts. Nama lengkapnya ialah Syam al-Dîn Abu Abdillah Muhammad bin Abi Bakr bin Ayyûb bin Sa'ad bin Huraiz al-Zar'i. Di dalam khazanah keilmuan, beliau lebih dikenal dengan sebutan Ibnu al-Qayyim al-Jauziyah. Sebutan ini lantaran ayah beliau adalah seorang ulama besar sekaligus kurator atau pengelola (qayyim) pada Madrasah al-Jauziyah di Damascus setelah

${ }^{2}$ Klaus Krippen Droff, Content Analysis Introduction to Its Theory and Methodology, ter. Farid Wajidi, (Jakarta: Raja Grafindo Persada, 1993), 15

326 JURNAL LISAN AL-HAL 
hancurnya salah satu Madrasah Hanâbilah terbesar di Damascus yang didirikan oleh Ibnu al-Jauzi (510 H./1126 M.-597 H./1200 M.). ${ }^{3}$ Dari jabatan ayahnya inilah sebutan ini diambil. Ia dilahirkan di daerah Zara', salah satu bagian dari perkampungan Hauran, sebelah tenggara Damsyq (Damaskus), Suriah, tepatnya pada tanggal 7 Shafar 691 H/ 4 Februari $1292 \mathrm{M}$.

Beliau dikenal sebagai seorang imam, 'allâmah, muhaqqiq, hâfidh, ushûli, faqîh, danahli nahwu. Di samping pakar di dalam ilmu fiqh dan ushûl fiqh, Ibnu al-Qayyim juga mempunyai pengetahuan yang mendalam tentang ilmu suluk, ilmu kalam, dan tashawwuf. Salah satu pemikiran yang khas Ibnu al-Qayyim ialah mengajak kembali kepada al-Qur'ân dan hadits serta memahaminya sesuai dengan pemahaman para al-salaf shâlih. Sehingga, ia dikenal sebagai seorang muslim puritan yang teguh memegang pendiriannya dalam mempertahankan kemurnian akidah dan anti taklid buta. Bahkan beliau memperingatkan kaum muslimin dari adanya khurafat ${ }^{4}$ kaum sufi, logika kaum filosof dan zuhud model orangorang Hindu ke dalam firqah Islamiyah. Baginya, pintu ijtihad selamanya tidak akan ditutup. Siapa saja berhak melakukan ijtihad selama orang tersebut mempunyai kualifikasi sebagai mujtahid.

Ibnu Qayyim al-Jauziyah, wafat pada malam Kamis, tanggal 13 Rajab tahun 751 H./ 26 September 1350 M. Setelah dishalatkan keesokan

3 Madrasah al-Jauziyah terletak di Damascus, desa al-Buzuriyah yang sekarang masih dikenal baik. Dalam perkembangan sejarahnya, madrasah ini pada tahun 1327 H./1910 M. dijadikan mahkamah oleh penguasa Syuriah, kemudian ditempati oleh Jam'iyah al-Is'âf al-Khairiyah (Yayasan Amal al-Khairiyah) dengan membuka sekolah taman kanak-kanak, sampai terbakar pada tahun 1925, ketika terjadi revolusi Syuriah menghadapi Perancis. Di Madrasah inilah Ibnu al-Qayyim memulai pendidikannya di bawah pengawasan langsung ayahnya. Lihat Ensiklopedi Hukum Islam, Vol. II, (Jakarta : PT. Ichtiar Baru van Hoeve, 2001), cet V, 616.

${ }^{4}$ Khurafat berasal dari kata kharifa-yakhrifu-kharfan-kharâfatan yang berarti sesuatu yang dipetik, cerita dusta, dan kisah yang mengandung unsur kebohongan dan kebatilan. Khurafat adalah kata yang mengacu kepada dongeng, kisah, legenda, cerita, asumsi, dugaan, kepercayaan, keyakinan, atau akidah yang tidak benar. Dr Ali Mahfudh, seorang ahli teologi Islam mendefinisikan khurafat dengan "sesuatu yang tidak dapat diterima oleh akal sehat"

Praktek Khurafat dapat terjadi dalam lapangan akidah, ibadah, dan mu'amalah. Dalam lapangan akidah misalnya, terdapat keyakinan yang datang dari luar Islam, seperti keyakinan masyarakat bahwa nasib mereka ditentukan oleh kekuatan-kekuatan sakti atau oleh arwah leluhur mereka. Dalam lapangan mu'amalat misalnya menanam kepala kerbau pada lokasi bangunan besar yang akan dibangun. Praktek ini didasarkan pada pandangan bahwa kepala kerbau dapat menjadi penangkal terhadap mara bahaya yang dapat menimpa bangunan yang akan didirikan. Ibid, Vol. III, 936-937. 
harinya usai shalat Dhuhur di Masjid Jami' Besar Dimasyq (Al-Jâmi' AlUmawi), ulama ini dimakamkan di pemakaman al-Bâb al-Shaghîr. ${ }^{5}$

\section{Rihlah ilmiah Ibnu al-Qayyim al-Jauziyah}

Sebagai seorang anak yang terlahir dari kalangan keluarga berilmu dan terhormat menjadikan kesempatan emas bagi Ibnu al-Qayyim untuk dapat mengeksplorasi segala daya kemampuannya dalam mengarungi lautan ilmu. Tidak heran jika dalam rihlah ilmiahnya Ibnu al-Qayyim banyak mengenyam beragam disiplin ilmu dari para ulama terkemuka pada masa itu. Terlebih ia hidup pada masa kejayaan ilmu pengetahuan dan didukung dengan pendidikan intensif yang diberikan oleh orang tuanya.

Dari ayahnya, Ibnu al-Qayyim belajar ilmu farâidl karena sang ayah memang sangat menonjol dalam ilmu itu. Selain itu, dia belajar bahasa Arab dari Ibnu Abi al-Fath al-Baththiy dengan membaca kitab-kitab $\mathrm{Al}$ Mulakhkhas li Abi al-Balqâ', kitab Al-Jurjâniyah, Alfiyyah Ibnu Mâlik, juga sebagian besar kitab Al-Kâfiyah was Syâfiyah dan sebagian kitab al-Tashîl. Kepada Syaikh Majd al-Dîn al-Tunisi dia belajar satu bagian dari kitab AlMuqarrib li Ibni Ushfûr. ${ }^{6}$

Dalam disiplin ilmu lainnya, Ibnu Qayyim berguru ilmu hadits pada Syihâb al-Nablusi dan Qadli Taqiy al-Dîn bin Sulaimân. Secara khusus, ia juga pernah belajar hadits pada Fâthimah Umm Muhammad binti Syekh Ibrâhîm yang lebih dikenal dengan nama Fâthimah Jauhar. Beliau belajar ilmu ushûl dari Syaikh Shafiy al-Dîn al-Hindi, ilmu fiqh dari Syaikh al-Islâm Ibnu Taimiyah dan Syaikh Ismâ'îl bin Muhammad al-Harrâniy. Dia pun terkenal dalam pengetahuannya tentang mazhab-mazhab Salaf.

Hingga akhirnya dia ber-mulâzamah secara total (berguru secara intensif) kepada Ibnu Taimiyah sesudah kembalinya Ibnu Taimiyah dari Mesir tahun 712 H. hingga wafatnya tahun 728 H. Ketika itu, Ibnu Qayyim sedang pada awal masa mudanya. Selama 16 tahun Ibnu al-Qayyim berguru kepada Ibnu Taimiyah. Di antara sekian banyak gurunya, yang paling banyak berpengaruh adalah Syaikh al-Islâm Ibnu Taimiyah. Ibnu alQayyim mengikuti metode gurunya ini dalam menentang dan memerangi orang-orang yang menyimpang dari agama. Sealur dengan gurunya, Ibnu al-Qayyim sangat gencar menyerang kaum filosof, Kristen, dan Yahudi.

Oleh karenanya, dia berkesempatan mereguk sumber ilmunya dari mata air yang luas. Pendapat-pendapat Ibnu Taimiyah yang penuh

\footnotetext{
${ }^{5}$ www.republika.co.id

${ }^{6}$ www.wikipediaindonesia.com

328 JURNAL LISAN AL-HAL
} 
kematangan dia cerna benar-benar. Ibnu al-Qayyim pun amat mencintainya, sampai-sampai dia mengambil kebanyakan ijtihadijtihadnya dan memberikan pembelaan atas pendapat-pendapat gurunya. Ibnu al-Qayyim juga menyebarluaskan ilmu Ibnu Taimiyah dengan cara menyusun karya-karyanya yang bagus dan dapat diterima.

Mereka berdua seakan tak terpisahkan. Ibnu al-Qayyim pernah dipenjara, dihina dan diarak berkeliling bersama Ibnu Taimiyah sambil didera dengan cambuk di atas seekor onta. Setelah Ibnu Taimiyah wafat, Ibnu al-Qayyim pun dilepaskan dari penjara. Cacian dan siksaan tersebut disebabkan karena beliau menentang adanya anjuran agar orang pergi berziarah ke kuburan para wali.

Banyak faedah besar yang dia petik selama berguru kepada tokoh kharismatik itu, di antaranya yang penting ialah berdakwah mengajak orang supaya kembali kepada kitab Al-Qur'ân dan sunnah Rasulullah, berpegang kepada keduanya, memahami keduanya sesuai dengan apa yang telah dipahami oleh al-Salaf al-Shâlih.

Ibnu al-Qayyim telah berjuang untuk mencari ilmu serta bermulâzamah bersama para ulama besar supaya dapat menyerap ilmu mereka dan supaya bisa menguasai berbagai bidang ilmu Islam. Kehausan ilmiah Ibnu al-Qayyim membuat ia mengembara untuk menuntut ilmu kepada beberapa ulama terkenal di zamannya, antara lain di Mesir dan Makkah, tempat bermukimnya para ulama besar masa itu.

Selain itu, Ibnu al-Qayyim juga merupakan seorang peneliti ulung. Dia menelaah semua ilmu dan segala tsaqâfah yang sedang jaya-jayanya pada masa itu di negeri Syam dan Mesir.

Intelektualitas dan integritas keilmuannya yang tidak diragukan lagi menjadi magnet yang ampuh untuk menarik orang-orang pilihan untuk menimba ilmu kepadanya. Pada realitasnya, Ibnu al-Qayyim berhasil mencetak murid-murid yang berkualitas. Selanjutnya, mereka tumbuh menjadi para ulama terbaik yang telah diakui keilmuannya, di antaranya ialah :

1. Putera beliau sendiri yang bernama Syaraf al-Dîn Abdullâh (ahli fiqh)

2. Putera yang lain bernama Ibrâhîm (ahli fiqh)

3. Ibnu Katsir al-Dimasyqiy (700 H./1300 M.-774 H./1373 M.), seorang ahli tafsir dan hadits penyusun kitab al-Bidâyah wa al-Nihâyah

4. Al-Imâm al-Hâfidh Abd al-Rahmân bin Rajab al-Hanbali al-Baghdâdi penyusun kitab Thabaqât al-Hanâbilah (736 H./1335 M.-795 H./1393 M.), ahli fiqh madzhab Hanbali.

5. Ibnu Abd al-Hâdi bin Qudâmah al-Maqdisi al-Shâlihi al-Hanbali (w.744 H.), ahli fiqh. 
6. Syams al-Dîn Muhammad bin Abd al-Qâdir al-Nablisiy.

7. Ibnu Abdirrahman al-Nablisiy.

8. Muhammad bin Ahmad bin Utsman bin Qaimaz al-Dzhahabi alTurkumaniy al-Syâfi'i (W. 748 H.), seorang muhaddits.

9. Ali bin Abd al-Kâfi bin Ali bin Tamâm Al-Subky (W. 756 H.), seorang ahli fiqh

10. Taqiy al-Dîn Abû al-Thâhir Muhammad bin Ya'qûb al-Fairuzabadi alSyâfi'i (W. 817 H.), seorang ahli fiqh

Selain dikenal sebagai ulama yang mendalam ilmunya, Ibnu alQayyim termasuk penulis yang produktif. Banyak karya-karya besar dari berbagai disiplin ilmu yang terlahir dari buah karya pikirnya. Oleh karenanya, beliau pantas disebut kamus segala pengetahuan ilmiah. Taha Abdur Rauf, ahli fiqh dan sejarawan menuliskan daftar karya Ibnu alQayyim sebanyak 49 buah. Yang terpenting di antaranya ialah Tahdzîb Sunan Abî Dawûd, Safar al-Hujrataian wa bâb al-Sa'âdatain, Madârij alSâlikîn, Syarh Asmâ' al-Kitâb al-'Azîz, Zâd al-Ma'âd fi Hâdy al-'Ibâd, Naqd alManqûl wa al-Mahq al-Mumayyiz baina al-Mardûd wa al-Maqbûl, Nuzhah al-Musytâqîn wa Raudlah al-Muhibbîn, Tuhfah al-Wadûd fi Ahkâm alMaulûd, Miftâh Dâr al-Sa'âdah, I'lâm al-Muwaqqi'în 'an Rabbil 'Âlamîn, Ighâtsah al-Lahfân fi Hukmi Thalaqil Ghadlbân, Ighâtsat al-Lahfân fi Mashâ 'id al-Syaithân, Badâi' al-Fawâ'id, Amtsâl al-Qur'ân, dan Buthlân alKimiya' min Arba'ina Wajhan. ${ }^{7}$

\section{Pemikiran Ushûl Fiqh Ibnu al-Qayyim al-Jauziyah}

Sebagai salah satu ulama' ushûl bermadzhab Hanbali, tentunya pemikiran Ibnu al-Qayyim tidak terlepas dari pokok-pokok kaidah ushûl fiqh madzhab Hanbali. Meskipun ada sebagian pendapat Ibnu al-Qayyim yang tidak sejalan dengan Imam Ahmad bin Hanbal, semisal penempatan posisi sunnah sebagai sumber hukum. Dalam pandangan Imam Ahmad bin Hanbal, al-Qur'ân dan sunnah mempunyai kedudukan yang sama, yaitu sebagai sumber pertama dan utama hukum Islam. ${ }^{8}$ Menurut Ibnu alQayyim, yang menjadi sumber utama dan pertama hanya al-Qur'ân. Sedangkan sunnah hanya berposisi sebagai runner up. ${ }^{9}$ Sehingga, Ibnu al-

${ }^{7}$ Ensiklopedi Islam, Vol II, (Jakarta : PT. Ichtiar Baru van Hoeve, 1994), cet II, 148149.

8 Posisi sunnah terhadap al-Qur'ân adalah sebagai tafsir dan bayân terhadap alQur'ân. Lihat Dr. Abdullâh bin Adbul Muhsin al-Turky, Ushûl Madzhab al-Imâm Ahmad, (Riyâdl : Maktabah al-Riyâdl al-Hadîtsah, 1977), cet II, 211.

9 Syams al-Dîn Abi Abdillâh Muhammad bin Abi bakar ibnu al-Qayyim, I'lâm alMuwaqqi'în, (Beirut : Dâr al-Fikr, tt), 288-289. Ensiklopedi Hukum Islam, Op cit, Vol II, $330 \mid$ JURNAL LISAN AL-HAL 
Qayyim mempunyai karakteristik tersendiri yang menjadi ciri khas pemikirannya.

Pemikiran fiqh dan ushûl fiqh Ibnu al-Qayyim lebih banyak dituangkan dalam karya magnum opusnya "I'lâm al-Muwaqqi'în" dan "alThuruq al-Hukmiyah". Dalam kitabnya ini, Ibnu al-Qayyim mengupas secara panjang lebar pemikirannya tentang ijtihad dan metode ijtihad.

Menurutnya, ijtihad selalu berkembang seiring dinamika perubahan zaman. Hukum harus relevan dengan situasi dan kondisi di berbagai tempat dan masa. Pemikiran ini merupakan refleksi dan sekaligus reaksi dari adanya opini umum di kalangan umat Islam ketika itu yang mempunyai asumsi bahwa pintu ijtihad telah ditutup.

Ibnu al-Qayyim secara lantang menyerukan dan memberikan spirit untuk memarakkan aktifitas berijtihad. Alasannya, hukum-hukum yang telah ada ketika itu sudah tidak relevan dengan perkembangan zaman dan tempat. Bahkan, ia mengecam keras sikap taklid para ulama di masanya.

Ibnu al-Qayyim mencanangkan penggunaan akal semaksimal mungkin dalam berijtihad. Alasannya, perubahan situasi dan kondisi memerlukan pemikiran yang jeli dan mendalam dalam memproduk hukum yang relevan. Dalam hal ini penggunaan rasio sangat menentukan. Dalam aktifitas berijtihad dengan rasio, Ibnu al-Qayyim menandaskan harus dibarengi dengan niat tulus dan ikhlas tanpa disertai dengan kecenderungan pribadi atau kepentingan tertentu.

Oleh sebab itu, ia membagi ijtihad melalui akal tersebut (ra'yu) menjadi tiga bentuk, yaitu al-ra'yu al-bâtil bilâ raibin ${ }^{10}$, al-ra'yu al-shahîh ${ }^{11}$,

619

10 Menurut Ibnu al-Qayyim, yang termasuk dalam kategori al-ra'yu al-bâtil ialah : pendapat yang bertentangan dengan nash, pendapat tentang agama dengan bersandar dugaan disertai betindak serampangan di dalam memahami dan meng-istinbâth-kan hukum dari nash, pendapat yang mengabaikan tuhan, sifat-sifat-Nya dan perbuatan-Nya, pendapat yang menimbulkan bid'ah dan mengubah ajaran Nabi (sunnah). Ibnu alQayyim, Op cit, Juz I, 67-69.

${ }^{11}$ Al-ra'yu al-shahîh disebut juga oleh Ibnu al-Qayyim dengan al-ra'yu al-mahmûd. Yang termasuk dalam kategori ini adalah : pendapat orang yang paling ahli fiqh, paling bersih hatinya, paling mendalam ilmunya yang mengetahui $t a^{\prime}$ wil dan memahami tujuan pensyari'atan, pendapat yang menjelaskan nash dan mempermudah melakukan istinbâth hukum dari nash, pendapat yang menjadi satu kesepakatan umat, pendapat yang diambil melalui pencarian dari al-Qur'ân. Jika tidak dijumpai, maka mencari di sunnah, jika tidak terdapat, maka mengambil pendapat yang telah diputuskan al-khulafâ' al-râsyidin atau yang diputuskan oleh salah satu sahabat Nabi. Jika masih tidak menemukan, maka berijtihad dengan pendapatnya sendiri yang mendekati dengan al-Qur'ân, sunnah, dan pendapat para sahabat. Ibid, 83-85. 
al-ra'yu al-musytabih. Bagian yang pertama dicela, tidak boleh diamalkan dan fatwakan. Bagian kedua dapat diamalkan dan difatwakan. Sedangkan yang ketiga dapat diamalkan dan difatwakan ketika kondisi darurat atau tidak dapat dielakkan lagi, tapi tidak harus diamalkan. ${ }^{12}$

Dalam rangka pengembangan hukum Islam sesuai dengan maqâshid al-syarî'ah, ia mengemukakan beberapa metode ijtihad. Metode yang dapat dipakai adalah ijmâ', qiyâs, al-maslahah al-mursalah, istishâb, 'urf, dan sadd al-dzarî'ah.

Di antara pemikiran ushûl fiqh Ibnu al-Qayyim yang paling menonjol dan memiliki kekhasan ialah tentang 'urf dan sadd al-dzarî'ah. Ia dikenal sebagai orang pertama yang merumuskan kaidah fiqh :

$$
\text { تغير الأحكام بتغير الأزمنة والأمكنة والأحوال }
$$

"Perubahan hukum sesuai dengan perubahan zaman, tempat, dan kondisi"13

Kaidah ini mengandung pengertian yang luas dalam berbagai aspek fiqh, karena syari'at Islam senantiasa mengacu pada kemaslahatan manusia, sedang kemaslahatan manusia sangat terkait erat dengan kondisi tempat, zaman, serta lingkungan yang mengitarinya. Pemikiran Ibnu alQayyim tentang sadd al-dzarî́ah akan dibahas lebih mendalam dalam ulasan berikut ini.

\section{E. Pandangan Ibnu al-Qayyim al-Jauziyah tentang Sadd al-Dzarî'ah}

Ibnu al-Qayyim mengartikan al-dzarî'ah dengan hal-hal yang dapat menjadi media dan jalan menuju sesuatu yang lain. Dalam beberapa karyakaryanya, Ibnu al-Qayyim pada biasanya menggunakan istilah al-dzarâi' sebagai bentuk plural dari al-dzarî'ah. Menurutnya, al-dzarâi' merupakan salah satu dalil ahkâm. Untuk mendukung pendapatnya ini, ia mengemukakan alur pikir berikut ini :

Setiap tujuan tidak akan tercapai tanpa melalui sebab dan media yang menjadi perantara. Media yang berfungsi sebagai pengantar adalah suatu keharusan yang tidak dapat diabaikan. Oleh karenanya, pengantar tersebut status hukumnya sama dengan tujuan yang akan dicapai.

Perantara pada suatu keharaman dan kemaksiatan akan dikenai hukum yang sama sebatas kemungkinannya dapat mengantar kepada keharaman. Sebaliknya, media kebaikan dan ibadah akan menyandang hukum yang sama sekadar dapat mengantar kepada kebaikan yang dimaksud. Berarti, pengantar pada suatu tujuan tertentu sama halnya

12 Ibid, 67.

13Ibid, Juz III, 14.

332 JURNAL LISAN AL-HAL 
dengan tujuan itu sendiri. Karena keduanya sama-sama dimaksudkan. Tujuan (ghâyah) dimaksud sebagai capaian akhir, sedangkan perantara (wasîlah) dimaksud sebagai pengantar.

Tatkala Allah mengharamkan suatu hal, sedangkan untuk dapat melakukannya membutuhkan suatu perantara, maka Allah juga mengharamkan perantara itu sebagai bentuk ketegasan larangan Allah. Seandainya Allah tidak mengharamkan perantara itu, sama halnya Allah membatalkan larangan-Nya. Hal ini selaras dengan hikmah dan ilmu Allah bahkan senada dengan nalar politik para penguasa di dunia. Sebagai contoh, apabila seorang komandan melarang kepada prajurit atau bawahannya akan melakukan sesuatu, sementara ia membolehkan hal-hal yang dapat menjerumuskan kepada larangan tersebut, berarti larangan ini menjadi mandul dan tidak dianggap. Contoh lain, Seorang dokter yang hendak mengobati penyakit pasien, ia pasti melarangnya melakukan sesuatu yang dapat membuat penyakitnya kambuh kembali. Sebab, jika sang dokter tidak melarangnya berarti dokter tersebut sia-sia mengobati pasien.

Jadi, untuk menentukan status hukum al-dzarî'ah, harus memandang pada tujuan yang akan dicapai. Jika tujuannya mengarah kepada sesuatu yang baik, maka harus dibuka jalan yang lebar bagi aldzarî̀ah sebagai pengantar kepada kemaslahatan. Hal ini pada biasanya disebut fath al-dzarî'ah. Sedangkan jika mengantar kepada mafsadat atau larangan, maka al-dzarî'ah harus ditutup rapat-rapat. Hal ini biasa disebut dengan sadd al-dzarî'ah. Akan tetapi, pada biasanya yang dimaksud dalam al-dzarî́ah adalah sesuatu yang mengantar kepada mafsadat, sehingga yang populer disebut adalah sadd al-dzarî̀ah.

Ibnu al-Qayyim membagi sesuatu yang dapat mengantar kepada kerusakan (mafsadat) menjadi dua bagian: 1) Sesuatu yang memang ditetapkan untuk mengantar kepada mafsadat, dan 2) Sesuatu yang semestinya ditetapkan untuk mengantar kepada suatu yang mubah atau sunnah, akan tetapi dijadikan perantara untuk mencapai tujuan yang haram, baik secara sengaja atau secara tidak sengaja.

Bagian kedua ini tercabang lagi menjadi dua bagian: 1) Mafsadatnya lebih dominan dari pada masahatnya, dan 2) Sisi kemaslahatannya lebih dominan. Jadi, dapat disimpulkan bahwa pembagian al-dzarâi' menurut Ibnu al-Qayyim ada empat macam, yaitu :

1. Sesuatu yang sejak semula dapat mengantar kepada mafsadat, misalnya minum khamr dapat membuat mabuk, menuduh zina dapat mengantar kepada membuat kedustaan, berzina dapat menyebabkan tercampurnya nasab. 
2. Sesuatu yang pada dasarnya merupakan media sesuatu yang boleh akan tetapi dijadikan perantara mencapai mafsadat, misalnya berakad nikah seraya bermaksud menghalalkan mantan suami yang mentalak tiga, melakukan jual beli dengan tujuan memperkenankan riba.

3. Sesuatu yang pada dasarnya merupakan media sesuatu yang mubah tanpa disertai tujuan mencapai mafsadat, akan tetapi lebih dominan cenderung mengantar kepada mafsadat, misalnya shalat sunnah di waktu-waktu yang dilarang, mencaci sesembahan orang musyrik di depan mata mereka, shalat di depan kuburan, beriasnya perempuan pada masa 'iddah karena wafatnya suami.

4. Sesuatu yang pada dasarnya merupakan media sesuatu yang mubah tanpa disertai tujuan mencapai mafsadat serta terdapat kemungkinan mengantar kepada mafsadat akan tetapi sisi maslahatnya lebih dominan, misalnya memandang kepada perempuan yang dipinang, melihat perempuan ketika bertransaksi, berkata jujur di hadapan penguasa yang dhalim.

Untuk bagian yang pertama, semua ulama sepakat bahwa hukumnya haram atau hanya sebatas makruh sesuai dengan kadar mafsadat yang ditimbulkan. Bagian yang keempat juga disepakati kebolehnnya, atau sunnah, atau bahkan wajib sebanding dengan tingkatan kemaslahatan yang dihasilkan. Untuk bagian kedua dan ketiga inilah yang menjadi ajang perdebatan. Apakah syara' menutupnya rapat-rapat agar mafsadat yang akan dihasilkan tidak terwujud ataukah syara' masih memberi kelonggaran untuk dilaksanakan? Dalam masalah ini Ibnu alQayyim memilih pendapat untuk menutup akses kepada mafsadat, yang biasa dikenal dengan sadd al-dzarî́ah.

Dalam menetapkan pemikirannya ini, Ibnu al-Qayyim mengajukan dalil tentang kehujjahan sadd al-dzarî'ah. Semua dalil yang diajukan berasal dari al-Qur'ân dan sunnah yang menjadi bukti kehujjahan sadd aldzarî'ah. Dalil-dalil tersebut antara lain:

1. Firman Allah dalam surat al-An'âm : 108

$$
\text { ولا تسبوالذين يدعون من دون الله فيسبوالله عدوا بغير علم : }
$$

"Dan janganlah kamu memaki sembahan-sembahan yang mereka sembah selain Allah, karena mereka nanti akan memaki Allah dengan melampaui batas tanpa pengetahuan"14

${ }^{14}$ Departemen Agama, al-Qur'an dan Terjemahnya, (Madinah: Mujamma' Khâdim al-Haramain), 205.

334 JURNAL LISAN AL-HAL 
Di dalam ayat ini Allah melarang mencaci sesembahan orang musyrik padahal hal itu dilakukan untuk membela Allah, akan tetapi di sisi lain dapat menyebabkan orang-orang musyrik membalas menghina Allah. Nampak jelas bahwa larangan ini bukan faktor menghina sesembahan orang kafir, tetapi larangan tersebut terletak pada dampak yang ditimbulkan dari perbuatan ini. Larangan Allah ini dalam rangka mengantisipasi munculnya akibat yang jelek. Inilah praktek sadd aldzarî’ah.

2. Firman Allah dalam surat : al-Nur : 31

$$
\text { ولا يضربن بأرجلهن ليعلم ما يخفين من زينتهن }
$$

"Danjanganlah mereka memukulkan kakinya agar diketahui perhiasan yang mereka sembunyikan."15

Ayat ini melarang perempuan menghentakkan kaki ke tanah dengan memakai gelang kaki. Sebenarnya perbuatan ini tidak terlarang, akan tetapi karena dapat menyebabkan menarik perhatian laki-laki sehingga dapat menimbulkan syahwat, maka perbuatan ini dilarang. Larangan ini merupakan bentuk sadd al-dzarî́ah.

3. Nabi melarang berkhalwat meskipun untuk membacakan al-Qur'ân, bepergian bersama perempuan lain meskipun untuk tujuan haji atau mengunjungi orang tua sebagai bentuk antisipasi dari terjadinya kemungkinan-kemungkinan yang tidak diperkenankan syara'.

4. Nabi melarang kepada para sahabat membunuh orang-orang munafik. Meskipun membunuh orang munafik nampak maslahatnya, akan tetapi Nabi melarangnya sebagai antisipasi akan adanya orang-orang yang menghindar dari Islam karena dimunculkan desas-desus bahwa Nabi Muhammad membunuh teman-temannya sendiri. Sikap Nabi ini merupakan manifestasi sadd al-dzarî́ah.

Sebenarnya masih banyak dalil yang dijadikan dasar Ibnu alQayyim untuk menetapkan kehujjahan sadd al-dzarî'ah. Ada sembilan puluh sembilan dalil yang diungkapkan Ibnu al-Qayyim dalam kitabnya I'lâm al-Muwaqqi'în. Dalil-dalil tersebut diambil dari al-Qur'ân atau hadits yang secara aplikatif menggunakan metode sadd al-dzarî́ah. Dengan alur pikir ini, Ibnu al-Qayyim berpandangan bahwa al-Qur'ân dan hadits mengakui praktek pengambilan hukum berdasarkan sadd al-dzarî'ah.

Dalam tataran praksis, Ibnu al-Qayyim sering menggunakan sadd al-dzarî'ah dalam memproduk hukum. Sebagai contoh, sekelompok orang secara keroyokan yang membunuh satu orang akan di-qishâsh seluruhnya, padahal semestinya aturan qishâsh harus seimbang. Jika menghilangkan

15Ibid, 548. 
nyawa satu orang, hukumannya juga dibunuh satu orang. Akan tetapi, ketentuan ini diberlakukan berdasarkan sadd al-dzarî̀ah. Alasannya jika tidak dibunuh semua dikhawatirkan banyak terjadi pertumpahan darah secara sia-sia, dalam arti para pelakunya tidak dikenai hukuman yang setimpal. 16

Keharaman khamr tidak memandang kadar yang diminum. Sedikit atau banyak sama-sama diharamkan. Walaupun meneguk sedikit saja tidak memabukkan, akan tetapi dapat berpotensi untuk mendorong minum khamr lebih banyak. Ketika minum khamr dalam kadar yang banyak, maka mengakibatkan mabuk. Ketika mabuk, pikiran menjadi tidak stabil sehingga menimbulkan permusuhan dan pertengkaran. Lebih dari itu, khamr juga haram disimpan dan dianggap najis. Ketentuan ini dalam rangka menutup rapat-rapat hal-hal yang dapat menghanyutkan seseorang untuk meneguk khamr. Keharaman minum khamr dengan kadar yang banyak karena membuat mafsadat, sedangkan keharaman minum khamr dengan kadar sedikit adalah berdasar pada sadd al-dzarî'ah. ${ }^{17}$

Sadd al-dzarî'ah ini diaplikasikan dalam semua kasus. Namun, dalam kitab Zâd al-Ma'âd, Ibnu al-Qayyim menandaskan sebagai berikut $: 18$

وتخريم الحرير إنما كان سدا للذريعة ولذا أبيح للنساء وللحاجة والمصلحة الراجحة وهذه قاعدة ما حرم لسد الذرائع

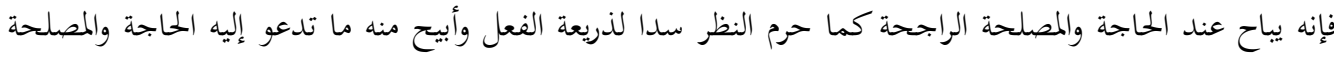

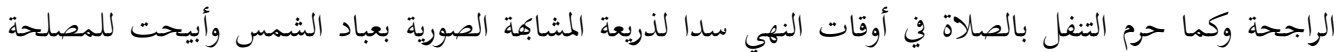

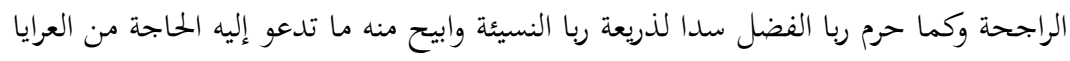

Dalam salah satu karyanya ini, Ibnu al-Qayyim memberi catatan bahwa sadd al-dzarî'ah dapat diterapkan apabila tidak bertentangan dengan hajat dan kemashlahatan. Jika terjadi pertentangan antara sadd aldzarî'ah dan mashlahat, maka mashlahat yang diunggulkan sebagaimana terdapat dalam salah satu karya Ibnu al-Qayyim :19

$$
\text { وقاعدة باب سد الذرائع إذا عارضه مصلحة راجحة قدمت عليه }
$$

16 Syams al-Dîn Abi Abdillâh Muhammad bin Abi bakar ibnu al-Qayyim, Ighâtsah alLahfân, (al-Maktabah al-Syâmilah), Juz I, 367.

17 Syams al-Dîn Abi Abdillâh Muhammad bin Abi bakar ibnu al-Qayyim, Al-Fatâwa al-Kubro, (al-Maktabah al-Syâmilah), Juz III, 259, Syams al-Dîn Abi Abdillâh Muhammad bin Abi bakar ibnu al-Qayyim, al-Furûsiyah , (al-Maktabah al-Syâmilah), 309.

18 Syams al-Dîn Abi Abdillâh Muhammad bin Abi bakar ibnu al-Qayyim, Zâd alMa'âd, (al-Maktabah al-Syâmilah), Juz IV, 78.

${ }^{19}$ Ibid, Juz V, 148.

336 JURNAL LISAN AL-HAL 
Dalam I'lâm al-Muwaqqi'în, Ibnu al-Qayyim menyebutkan :20

$$
\text { لأن باب سد الذرائع متى فاتت به مصلحة راجحة او تضمن مغسدة راجحة لم يلتفت إليه }
$$

Dalam redaksi yang berbeda, Ibnu al-Qayyim menegaskan bahwa sadd al-dzarî'ah tidak dapat ditetapkan ketika mengabaikan kemaslahatan atau menimbulkan mafsadat yang lebih besar. Sebagai contohnya ialah melihat perempuan diharamkan karena dapat mengantarkan kepada perbuatan keji. Akan tetapi larangan ini tidak berlaku jika terdapat kebutuhan (hajat) dan kemasalahatan untuk melihat semisal untuk meminang, bertransaksi, bersaksi, dan sebagainya. Shalat sunnah di waktu-waktu yang dilarang adalah haram karena dapat dianggap menyerupai orang-orang kafir yang menyembah matahari. Sebab, di waktu itulah orang-orang kafir ini menyembah mataahari. Akan tetapi ketika terdapat kemaslahatan tertentu, maka tidak diharamkan shalat di waktu yang dilarang. Keharaman memakai sutera bagi laki-laki berdasarkan sadd al-dzarî'ah, makanya diperbolehkan bagi perempuan dan bagi laki-laki untuk kemaslahatan tertentu, misalnya bagi orang yang berpenyakit gatal, suhu terlalu panas. Riba al-Fadl diharamkan dalam rangka menutup kemungkinan terjadinya riba nasî'ah ${ }^{21}$, akan tetapi praktek riba $\mathrm{Fadl}^{22}$ diperbolehkan dalam jual beli 'arâya ${ }^{23}$ karena ada kebutuhan.

Disebabkan saking banyaknya kasus-kasus yang dihukumi berdasarkan sadd al-dzarî́ah, Ibnu al-Qayyim menyatakan bahwa sadd aldzarî'ah merupakan seperempat taklif. Sebab, taklif terdiri dari perintah dan larangan. Perintah mencakup dua hal; yakni sesuatu yang dimaksud untuk diperintahkan dan sesuatu yang dapat mengantar kepada suatu yang diperintahkan. Sedangkan larangan juga mencakup dua hal, yakni sesuatu yang memang mengandung mafsadat dan sesuatu yang dapat mengantar kepada mafsadat. Kesimpulannya, sesuatu yang menjadi wasîlah kepada keharaman merupakan seperempat dari agama. ${ }^{24}$

Dengan berpegang pada konsep sadd al-dzarî'ah, Ibnu al-Qayyim

${ }^{20}$ Ibnu al-Qayyim, I'lâm al-Muwaqqi'în, Op cit, Juz III, 165.

${ }^{21}$ Riba nasi'ah ialah menjual barang ribawi dengan bertempo atau tidak kontan. Abdullah bin Hujazi bin Ibrahim al-Syarqawi, Hasyiyah al-Syarqawi, Juz II, (Beirut : Dar alFikr, $\mathrm{tt}), 30$.

${ }^{22}$ Riba fadl adalah menjual barang ribawi dengan ada kelebihan salah satu barang yang dipertukarkan. Ibid, 30 .

${ }^{23}$ Jual beli 'araya ialah menukar kurma yang sudah kering dengan kurma yang masih di atas pohon. Abi Zakariyâ Muhyiddîn bin Syaraf, al-Majmû'Syarh al-Muhadzdzab, (Beirut : Dâr al-Fikr, tt), Juz XI, 2.

${ }^{24}$ Ibnu al-Qayyim, I'lâm Muwaqqi'în, Op cit, Juz III, 171. 
menegaskan bahwa hîlah (merekayasa hukum) diharamkan. Menurutnya, membolehkan hîlah berarti bertentangan dengan sadd al-dzarî'ah. Alasannya, Syari' menutup rapat-rapat semua media yang memungkinkan sampai kepada mafsadat. Sedangkan orang yang melakukan hîlah bermaksud untuk membuka jalan kepada mafsadat dengan cara rekayasa. ${ }^{25}$

Dalam kitab Ighâtsah al-Lahfân, Ibnu al-Qayyim menuturkan :26

$$
\begin{aligned}
& \text { فصل وإذا تدبرت الشريعة وجدةما قد أتت بسد الذرائع إلى المحرمات وذلك عكس باب الحيل الموصلة إليها فالحيل }
\end{aligned}
$$

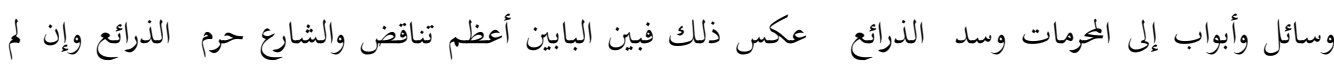

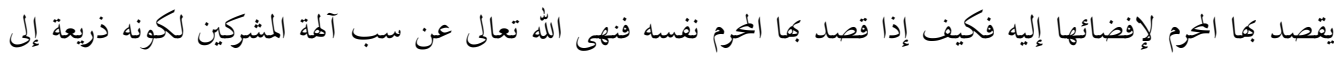

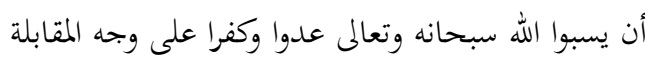

Dalam kitab ini, Ibnu al-Qayyim lebih menegaskan lagi bahwa sadd al-dzarî’ah kontradiksi dengan hîlah. ${ }^{27}$ Sadd al-dzarî̀ah ditetapkan dalam rangka mengantisipasi terjadinya keharaman, sementara hîlah berorientasi kepada usaha-usaha untuk melegalkan suatu yang haram. Bahkan, meskipun seseorang tidak bermaksud kepada mafsadat tersebut, asalkan perbuatannya dapat mengantar kepada mafsadat, maka harus diantisipasi dan dicegah. Ini merupakan prinsip sadd al-dzarî'ah. Dalam kitab Ighâtsah al-Lahfân, Ibnu al-Qayyim menegaskan :28

$$
\text { وهذا كله حرام على من قصده ومن لم يقصده بل على من قصد خحلافه سدا للذريعة }
$$

Dalam halaman berikutnya, Ibnu al-Qayyim menjelaskan secara rinci bahwa sesuatu yang diharamkan terdiri dari dua, yaitu mafasid dan media kepada mafasid. Sesuatu yang menjadi media terhadap mafasid ini diharamkan juga sejalan dengan mafasid itu sendiri. Demikian pula

25 Ibid, 171.

${ }^{26}$ Ibnu al-Qayyim, Ighâtsah al-Lahfân, Op cit, Juz I, 361.

27 Hîlah secara bahasa adalah kecerdikan, kemampuan bertindak, tipu daya (muslihat), alasan yang dicari-cari untuk melepaskan diri. Lihat; KH. Ahmad Warsun Munawir, "Kamus Al-Munawwir Arab-Indonesia", (Surabaya : Penerbit Pustaka Progresif, 1997), cet XIV, 311. Secara terminologi, hîlah ialah melakukan suatu amalan yang pada lahirnya diperbolehkan untuk membatalkan hukum syara' lainnya. Misalnya, seseorang menghibahkan hartanya. Hibah tersebut dilakukan ketika masa haul (satu tahun) sudah mendekat, seperti beberapa hari sebelum haul dan nisab harta yang wajib dizakatkan pun telah tercapai. Secara lahir, tindakan menghibahkan harta tersebut sangat terpuji. Akan tetapi, jika orang tersebut sengaja melakukan hibah mendekati kewajiban zakat, berarti dia bermaksud lari dari kewajiban zakat, karena dengan dihibahkan sebagian hartanya, maka nisab zakat menjadi tidak tercapai lagi. Jadi, hibah sebagaimana di atas merupakan hîlah untuk menghindari kewajiban zakat. Ensiklopedi Hukum Islam, Vol. II, 553-554.

28 Ibnu al-Qayyim, Ighâtsah, Op cit, Juz I, 362.

338 JURNAL LISAN AL-HAL 
kebaikan ada dua, mashâlih, dan media kepada mashâlih. Pengantar kepada mashâlih ini harus diberi jalan kebolehan (fath al-dzarî́ah) sebagaimana pengantar kepada mafasid harus ditutup (sadd al-dzarî'ah).

Lebih lanjut Ibnu al-Qayyim menjelaskan tentang sesuatu yang dapat mengantar kepada keharaman, akan tetapi pelakunya tidak bermaksud mencapai mafsadat tersebut. Berikut ini ungkapan Ibnu alQayyim dalam kitab Ighâtsah al-Lahfân :29

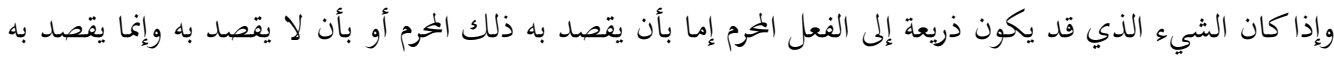

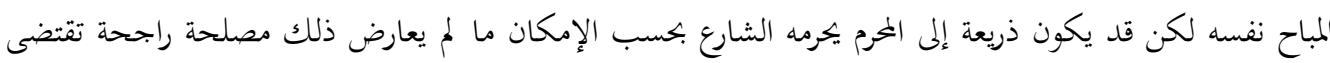

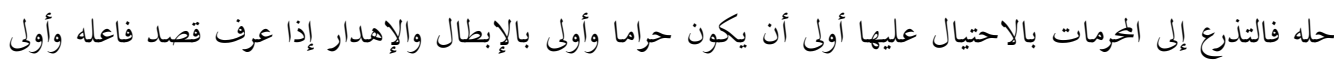

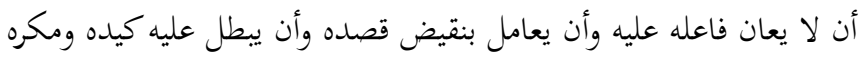

\section{F. Simpulan}

Dalam pandangan Ibnu al-Qayyim, al-dzarî'ah diartikan secara umum, artinya mencakup media yang mengantarkan kepada masalahat dan mafsadat. Baginya, al-dzarî'ah (perantara) dihukumi sama dengan ghâyah (tujuannya). Jika ghâyah-nya berupa kemaslahatan, maka diperkenankan. Jika berupa mafsadat, maka ditutup dan cegah. Yang terakhir inilah yang disebut sadd al-dzarî'ah. Jadi, kalau menyebut term sadd al-dzarî́ah berarti yang dimaksud ialah menutup sesuatu yang mengantar kepada mafsadat. Kalau mengantar kepada maslahat, disebut fath al-dzarî'ah.

Ibnu al-Qayyim mengakui kehujjahan sadd al-dzarî’ah sebagai dalil untuk menetapkan hukum. Diantara Argumentasinya ialahbanyak ayatayat al-Qur'ân dan hadîts yang mempraktekkan konsep sadd al-dzarî́ah. Dari sini ia memahami bahwa al-Qur'ân dan sunnah melegalkan praktek sadd al-dzarî̀ah.

Bahkan, menurutnya praktek sadd al-dzarî̀ah sama halnya menetapkan hukum berdasar pada dugaan semata. Sementara nash secara sharîh melarang hal ini.Contoh sebagian kasus yang penetapan hukumnya menggunakan saddal-dzarî́ah adalah berduaan di tempat sepi dengan seorang perempuan diharamkan karena dapat mengundang kepada mafsadat, yakni berbuat zina. Minum sedikit khamr diharamkan meskipun tidak menyebabkan mabuk karena dapat memotivasi untuk minum lebih banyak sehingga mabuk, Dilarang mencaci maki berhala di hadapan orang musyrik karena dikhawatirkan orang-orang musyrik tersebut akan memaki-maki Allah, dan lain-lain.

29Ibid, 370. 


\section{DAFTAR PUSTAKA}

Abdullah bin Hujazi bin Ibrahim al-Syarqawi, Hasyiyah al-Syarqawi, Juz II, Beirut : Dar al-Fikr, tt.

Abi Zakariyâ Muhyiddîn bin Syaraf, al-Majmû'Syarh al-Muhadzdzab, Beirut : Dâr al-Fikr, Juz XI. tt.

Departemen Agama, al-Qur'an dan Terjemahnya, Madinah: Mujamma' Khâdim al-Haramain.

Dr. Abdullâh bin Adbul Muhsin al-Turky, Ushûl Madzhab al-Imâm Ahmad, Riyâdl : Maktabah al-Riyâdl al-Hadîtsah, 1977.

Ensiklopedi Hukum Islam, Vol. II, Jakarta : PT. Ichtiar Baru van Hoeve, cet V, 2001.

Ensiklopedi Islam, Vol II, Jakarta : PT. Ichtiar Baru van Hoeve, cet II, 1994.

Ibnu al-Qayyim, I'lâm al-Muwaqqi'în, Juz III

Ibnu al-Qayyim, I'lâm Muwaqqi'în, Juz III

Ibnu al-Qayyim, Ighâtsah al-Lahfân, Juz I

KH. Ahmad Warsun Munawir, "Kamus Al-Munawwir Arab-Indonesia", Surabaya : Penerbit Pustaka Progresif, cet XIV, 1997.

Syams al-Dîn Abi Abdillâh Muhammad bin Abi bakar ibnu al-Qayyim, Ighâtsah al-Lahfân, al-Maktabah al-Syâmilah.

Syams al-Dîn Abi Abdillâh Muhammad bin Abi bakar ibnu al-Qayyim, AlFatâwa al-Kubro, al-Maktabah al-Syâmilah. Juz III.

Syams al-Dîn Abi Abdillâh Muhammad bin Abi bakar ibnu al-Qayyim, alFurûsiyah, al-Maktabah al-Syâmilah.

Syams al-Dîn Abi Abdillâh Muhammad bin Abi bakar ibnu al-Qayyim, Zâd al-Ma'âd, al-Maktabah al-Syâmilah, Juz IV.

1Syams al-Dîn Abi Abdillâh Muhammad bin Abi bakar ibnu al-Qayyim, I'lâm al-Muwaqqi'în, (Beirut : Dâr al-Fikr, tt.

www.republika.co.id

www.wikipediaindonesia.com

$340 \mid$ JURNAL LISAN AL-HAL 